\title{
フィードバック補償オンオフ制御装置の調整条件†
}

\author{
米沢洋・五郎丸 剛 志・石 橋剛 \\ 九州工業大学 北九州市戸烟区仙水町 1 \\ (昭和 42 年 12 月 4 日受付)
}

\section{A Setting Condition of the On-Off Controller with the Feedback Compensator}

\author{
Yoo Yonezawa, Tsuyoshi Gorōmaru and Katashi Ishibashi \\ (Kyūshū Institute of Technology, Kitakyūshū) \\ (Received December 18, 1967)
}

\begin{abstract}
In recent years the behavioure of on-off control system with feedback compensation has been improved, and some setting conditions of the on-off controller have been proposed. However one of the defects by these setting conditions in practice is that the offset cannot be reduced to zero.

In order to get time optimal response and zero offset when the set point is largely changed stepwise a new setting condition of the feedback compensated on-off controller which has the first order lag and dead time element is proposed.

As a result of the analog computer study on the responses of the on-off control system, it is found that the proposed setting condition is especially effective to the large step change of the set point
\end{abstract}

\section{1. は しがき}

通常のオンオフ・フィードバック制御系の欠点であ る定常応答を改善するための一手法として, フィード バック補償オンオフ制御が考えられ，わが国に沶いて もいくつかの研究 ${ }^{1 \sim 4}$ とよってその有用性が確認され， さらに, このフィードバック補償オンオフ制御の調整 条件報告 ${ }^{5 \sim 6)}$ された。これらの調整条件について種 々の見地から検討された結果, 制御対象に含まれるむ ボ時間に対する制御効果は著しいが，その反面，オン オフ要素のヒステリシス幅の影響は無視できないこと， また定常制御偏差をなくすことができないことなどが 淜らかになった

本研究では，Fig. 1 亿示すようなむだ時間を含导 1 次遅孔特性の制御対象を制御するフィードバック補 償オンオフ制御装置のパラメータを決定する一方法に ついて論ずる。ここでは比較的大きく突変される設定 值に対し, 制御量が最短時間応答を行ない, しか子定 一常制御偏差がゼロになるように制御装置のパラメータ を調整することを目的とする。

† 第 6 回計測自動制御学会学術講演会で発表 $($ 昭42・10・15)

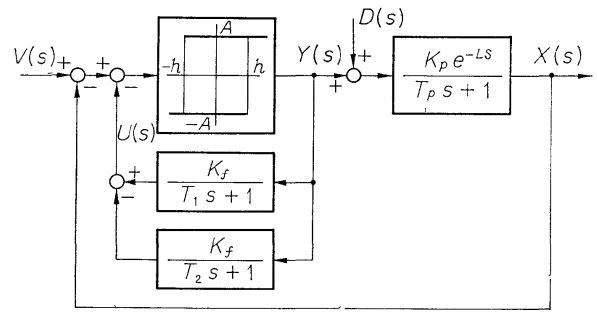

Fig. 1 The block diagram of feedback compensated on-off control system

\section{記号}

$A:$ オンオフ要素の出力

$d(t)$ : 制御系に作用する外乱

$D(s)=\mathcal{L}[d(t)]$

$2 h:$ オンオフ要素のヒステリシス幅

$K_{p}:$ 制御対象の比例ゲイン

$K_{f}:$ 補償要素の比例ゲイン

$L ：$ 制御対象のむだ時間

$P:$ 制御系の定常振動周期

$s:$ ラプラン変換演算子

$t:$ 時間

$t_{n}$ : 定常時でのオンオフ要素のオン時間 
$t_{f}$ ：常時でのオンオフ要素のオフ時間

$t_{s}:$ 設定値変更以後オンオフ要素が最初比換 わる時刻

$T_{p}$ : 制御対象の時定数

$T_{1}, T_{2}$ ： 補償要素の時定数

$U(t)$ : 補償要素の出力

$U_{d a}$ ： 補償要素の出力の定常複振幅

$U(s)=\mathcal{L}[U(t)]$

$v(t)$ ：設定値

$V(s)=\mathcal{L}[v(t)]$

$V_{0}: \quad t<0$ に特ける設定值

$V_{n}: t \geq 0$ 亿特ける設定値

$x(t)$ : 制御量

$x_{a v}$ ： 制御量の定常時にお打る平均値

$x_{d a}:$ 制御量の定常複振幅

$X(s)=\mathcal{L}[x(t)]$

$y(t)= \pm A:$ 操作量

$Y(s)=\mathcal{L}[y(t)]$

$\tau=t_{n} / P: \quad$ デューティサイクル

\section{2. 調 整条 件}

調整条件を求めるにさいし，つぎの仮定を和く。

（i）定常状態に括ける制御量の振動振幅は，設定 值変更前後子も制御可能範囲飞比較して十分小

(ii) Fig. 2 飞打いて $t_{s}>L$

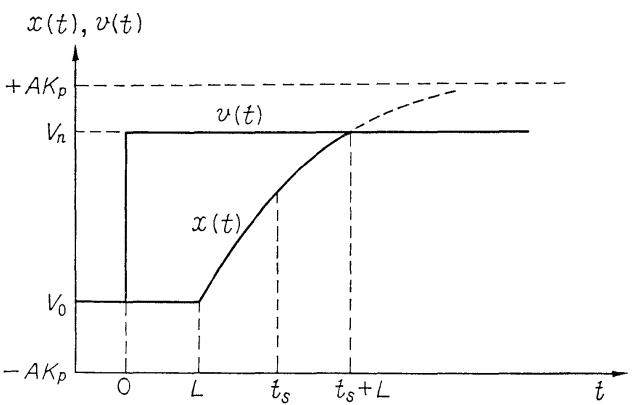

Fig. 2 Optimum response of $x(t)$ for step change of $v(t)$

（iii）オンオフ要素のヒステリシス幅は比較的小 な㧍，フィードバック補償要素の伝達関数 $H(s)$ が つぎの式で表わされる場合について考察する.

$$
H(s)=\frac{U(s)}{Y(s)}=-\frac{K_{f}}{T_{1} s+1}-\frac{K_{f}}{T_{2} s+1}
$$

\section{$2 \cdot 1$ 過渡状態}

Fig. 2 亿示すように， $t=0$ で設定値を $V_{0}$ から $V_{n}$ 飞突変する. $t=t_{s}(>0)$ でオンオフ要素が最初の切換 を行ならためには，

$$
x\left(t_{s}\right)+U\left(t_{s}\right)=V_{n}+h
$$

でなければならない。ところで，制御量が最短時間で 新しい設定值に到達するためには少なくとも，

$$
x\left(t_{s}+L\right) \geqq V_{n}
$$

であることが必要である，しかし，不等号の場合はと うぜん制御量行きすぎが生じ，好ましくないから等 号の場合についてのみ考察する. Fig. 1 亿示す制御 対象の伝達特性から（3）式は,

$$
V_{0} e^{-t_{s} / T_{p}}+A K_{p}\left(1-e^{-t_{s} / T_{p} p}\right)=V_{n}
$$

となり，これより最初の切換時点の式，

$$
t_{s}=-T_{p} \ln \left(\frac{1-V_{n} / A K_{p}}{1-V_{0} / A K_{p}}\right)
$$

が得られる。

$t<0$ では制御量と補償要素の出力の振動成分は設 定值変更量 $\left|V_{n}-V_{0}\right|$ 飞比較して十分小さいから無視 すれば（2）式は，

$$
\begin{aligned}
V_{0} e^{-\left(t_{s}-L\right) / T_{p}} & +A K_{p}\left(1-e^{-\left(t_{s}-L\right) / T_{p}}\right) \\
& +\left(V_{0} \cdot K_{f} / K_{p}-A K_{f}\right)\left(e^{-t_{s} / T_{1}}-e^{-t_{s} / T_{2}}\right) \\
& =V_{n}+h
\end{aligned}
$$

と書き改められるから，これに（4）式を代入すると 第 1 回目の最適切換条件式（5）を得る.

$$
\begin{aligned}
& \left(1-\frac{V_{n}}{A K_{p}}\right)\left(1-e^{L / T p p}\right)-\frac{h}{A K_{p}}-\frac{K_{f}}{K_{p}} \cdot\left(1-\frac{V_{0}}{A K_{p}}\right) \\
& \quad \times\left\{\left(\frac{1-V_{n} / A K_{p}}{1-V_{0} / A K_{p}}\right)^{T_{p} / T_{1}}-\left(\frac{1-V_{n} / A K_{p}}{1-V_{0} / A K_{p}}\right)^{T p / T_{2}}\right\}=0
\end{aligned}
$$

\section{$2 \cdot 2$ 定常状態}

補償要素からの出力の定常複振幅 $U_{d a}$ は,

$$
\begin{aligned}
U_{d a} & =2 A K_{f}\left\{\frac{2-e^{-\tau P / T_{1}}-e^{-(1-\tau) P / T_{1}}}{1-e^{-P / T_{1}}}\right. \\
& \left.-\frac{2-e^{-\tau P / T_{2}}-e^{-(1-\tau) P / T_{2}}}{1-e^{-P / T_{2}}}\right\}
\end{aligned}
$$

で与党られる ${ }^{9}$. 定常状態では仮定（i）により, 制 御量の桭動成分は制御可能範囲飞比較して十分小さい から, オンオフ要素の切換注補賞要素の出力信号に注 とんぞ依存することになる。すなわち，(6) 式の複 振幅は $2 h$ に等しくなければならないから，

$$
\begin{aligned}
& \frac{K_{f}}{K_{p}}\left\{\frac{2-e^{-\tau P / T_{1}}-e^{-(1-\tau) P / T_{1}}}{1-e^{-P / T_{1}}}\right. \\
& \left.-\frac{2-e^{-\tau P / T_{2}}-e^{-(1-\tau) P / T_{2}}}{1-e^{-P / T_{2}}}\right\}=\frac{h}{A K_{p}}
\end{aligned}
$$

が成立する。他方, 制御量の複振幅 $x_{d a}$ は次式9で与 えられる。

$$
x_{d a}=2 A K_{f}\left\{\frac{2-e^{-\tau P / T p}-e^{-(1-\tau) P / T p}}{1-e^{-P / T p}}-1\right\}
$$

この関係を Fig. 3 亿示す。を，定常時での制御量 の時間平均值仗 $x_{a v}=(1 / P) \int_{i P}^{\overline{\imath+1} P} x d t(i=0,1,2, \cdots)$ で与兄られ9)， 


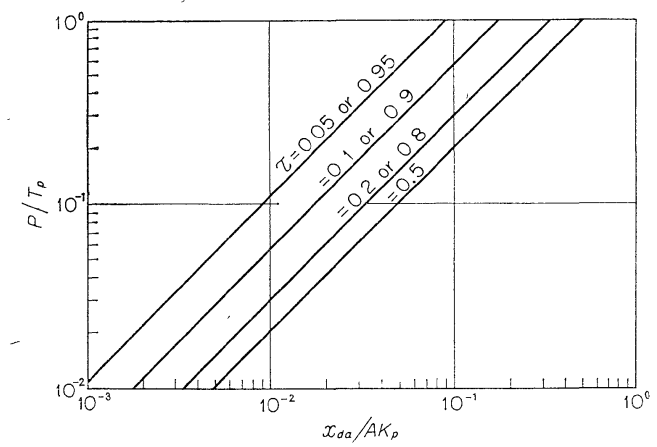

Fig. 3 Relation, between $P$ and $x_{d a}$

$$
x_{a v}=A K_{p}(2 \tau-1)
$$

となるから定常制御偏差がゼロとなるためには，

$$
\tau=0.5\left(1+V_{n} / A K_{p}\right)
$$

でなければならない。

\section{$2 \cdot 3$ 調整条件の誘導}

上述した過渡状態と定常状態に和将るそれぞれの条 件式を満足するようにオンオフ制御装置の調整パラメ 一夕を決定する。

まず，（9）式から新しい設定值に対する定常制御 偏差がセ口となるためのてを求め，このてに対して制 御量の複振幅が十分小さくするような $P$ の值を $(8)$ 式 より求める. このてとPに対して定常状態に抢ける切 換条件式（7）を満足し，かつ最短時間応答のための 最初の切換条件式（5)をる同時に満定するよらな $K_{f}, T_{1}$ および $T_{2}$ を求める. $T_{2}=T_{p}$ と仮定して得 られた計算結果例を Fig. 4 に示す.

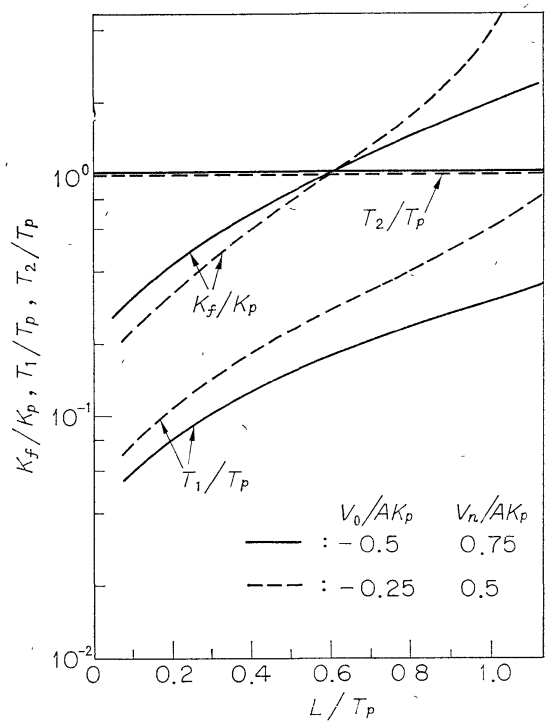

Fig. 4 Optimum values of ajustable parameters (h/AK $/ A K_{p}=0.05, P / T_{p}=0.1$ )

\section{3. アナコムによる計算結果および検討}

Fig. 1 の制御系をアナログ計算機で構成し，上述の 調整条件を適用して得られた結果を Fig. 5 特よび Table 1 に示す.ただしここでは $h / A K_{p}=0.05$ ， $P / T_{p}=0.1$ としてある.これらによれば，泀とんど希 望ど括りの応答が得られていることがわかる。ただ， 制御量にわずかの行きすぎが見らけられ，むだ時間が 大きいときに顕著である。これは $t=t_{s}$ 以後に和る オンオフ要素の過渡的切換による.

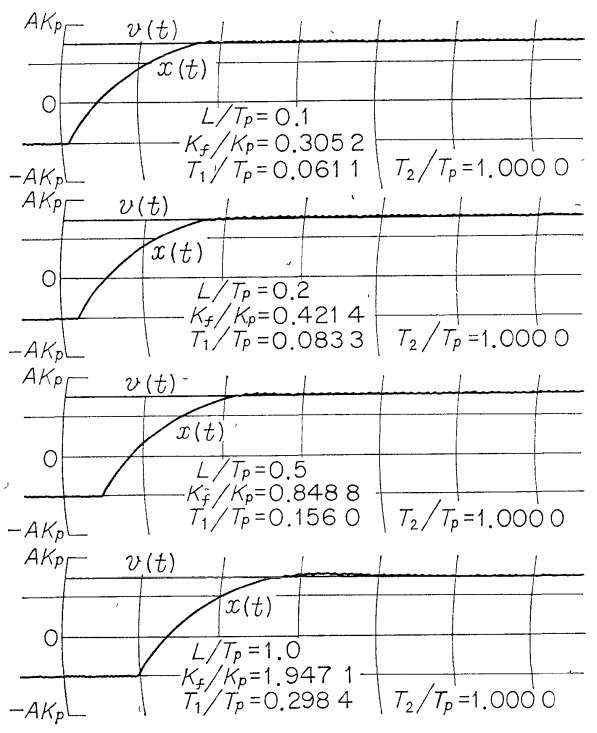

\begin{tabular}{|c|c|c|c|c|c|}
\hline \multirow{2}{*}{$L / T_{p}$} & \multicolumn{2}{|c|}{ desired value } & \multicolumn{3}{|c|}{ obtained value } \\
\hline & $P / T_{p}$ & $\tau$ & $P / T_{p}$ & $\tau$ & offset $/ A K_{p}$ \\
\hline 0.1 & 0.1 & 0875 & 0.096 & 0.882 & -0.014 \\
\hline 0.2 & 01 & 0875 & 0.098 & 0.882 & -0.014 \\
\hline 05 & 01 & 0.875 & 0.114 & 0.879 & -0.008 \\
\hline 1.0 & $0.1^{\prime}$ & 0.875 & 0.120 & 0.879 & -0.008 \\
\hline
\end{tabular}

Fig. 5 Step responses of controlled variable

Table 1 Estimation of results of analog computation

周期 $P$ の值が希望值と多少異なる理由としては，調 整条件の誘導にさいして, 制御量の振動成分がオンオ フ要素の切換にはなんら関与しないと仮定したためと 考えられる.Pの值が大きくなると, 制御量が新しい 設定値に到達した後の応答が良好でない，逆に，Pの 值が小さいときには制御量に生じた行きすぎがなかな か回復しない傾向がある.オンオフ要素のヒステリシ ス幅が大きくなると，一般に制御量の定常振動振幅が 大きくなるが，これを押さえるために $K_{f}$ の值を大き くすると， Fig. 2 の $t_{s}$ 以前でもオンオフ要素の切換 が生じ，最短時間応答を得ることができない。 


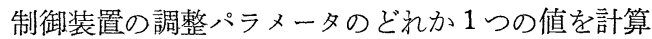
值から $10 \%$ だけ異なった值に調整した場合の応答 をFig. 6 特よび Table 2 に示す。ただし $h / A K_{p}=$ $0.05, P / T_{p}=0.1$ かつ $L / T_{p}=0.5$ の場合である. こ れらによれば， $K_{f}$ あるいは $T_{2}$ の值を大きくすると，

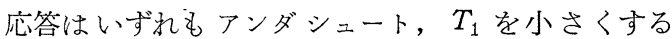
とオーバシュートを生ずる、傾向を有している。しか し，その傾向はあまり著しくなく，乙たがって制御装 置のパラメータを多少不完全な值に調整しても，その 影響はあまり大きくないことがわかる。

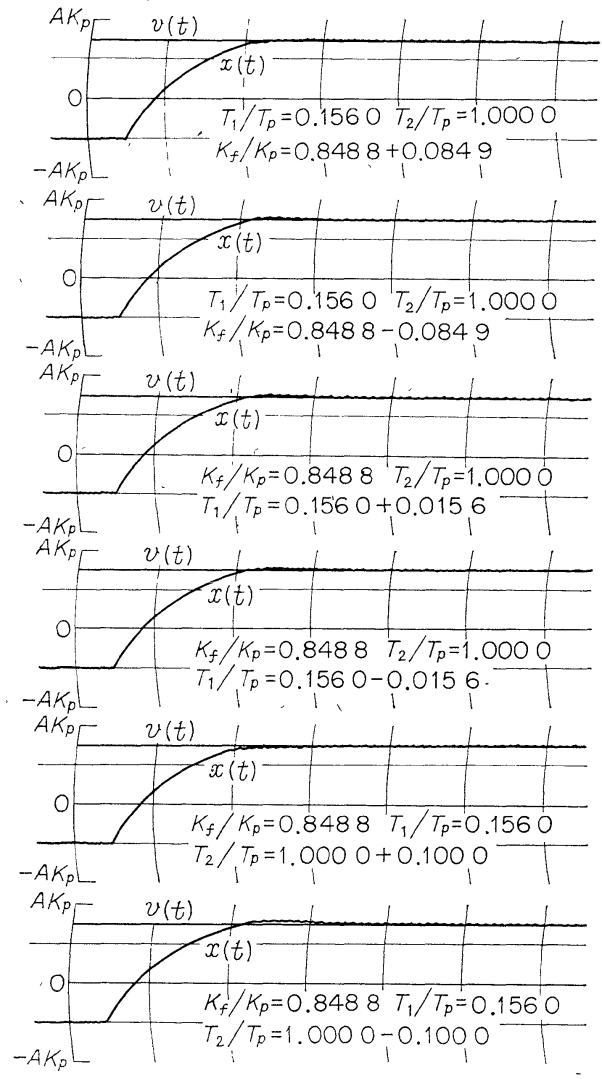

Fig. 6 Effects on ajustable parameter deviation on step response

\begin{tabular}{|c|c|c|c|c|c|}
\hline $\begin{array}{l}\text { para- } \\
\text { meter }\end{array}$ & $\begin{array}{l}\text { optimum } \\
\text { value }\end{array}$ & $\begin{array}{l}\text { devi- } \\
\text { ation } \\
{[\%]}\end{array}$ & $P / T_{p}$ & $\tau$ & offset $/ A K_{p}$ \\
\hline$K_{f} / K_{p}$ & 0.8488 & $\begin{array}{r}10 \\
-10\end{array}$ & $\begin{array}{l}0.108 \\
0.121\end{array}$ & $\begin{array}{l}0.884 \\
0.875\end{array}$ & $\begin{array}{l}-0.018 \\
0\end{array}$ \\
\hline$T_{1} / T_{p}$ & 0.1560 & $\begin{array}{r}10 \\
-10\end{array}$ & $\begin{array}{l}0.123 \\
0.099\end{array}$ & $\begin{array}{l}0.876 \\
0.876\end{array}$ & $\begin{array}{l}-0.002 \\
-0.002\end{array}$ \\
\hline$T_{2} / T_{p}$ & 1.0000 & $\begin{array}{r}10 \\
-10\end{array}$ & $\begin{array}{l}0.114 \\
0.117\end{array}$ & $\begin{array}{l}0.879 \\
0.880\end{array}$ & $\begin{array}{l}-0.008 \\
-0.010\end{array}$ \\
\hline
\end{tabular}

Table 2 Effects of ajustable parameter deviation on step response

\section{4.あとがき}

本論文では, Fig. 1 のような制御系で比較的大き な設定値変更に対して最短時間応答, 定常制御偏差ゼ 口を目的としたオンオフ制御装置の調整条件を得る一 方法について述べた。アナログ計算機の計算結果より， ほ添希望どうりの応答が得ら杞ることが判明した. 本 方法の特徴は, 最短時間応答を得るために新, 旧両設 定值を考慮した点であるが，定常振動周期が大きい場 合，扔よびオンオフ要素のヒステリシス幅が大きい場 合には適用困難な欠点を有する。

つねにご指導・ご鞭達をいただいている京都大学椹 木義一教授に深甚な謝意を表明する。

\section{引用 文 献}

1) 椹木, 米沢 : Existing Conditions for Self-Oscillation in an Improved On-Off Control System, 京 都大学工学部紀要 XXV-4，359/370 (1963)

2) 山口，伊沢 : オンオフ制御系の改善, 計測と制御, 37, 512/519 (1964)

3）、山口：オンオフ制御装置の設計法，計測と制御，3-7, $519 / 528$ (1964)

4）古谷，山口：補償のあるオンオフ制御系に晾忷るリミ ットサイクル，計測自動制御学会論文集，1-4，339/ 348 (1965)

5）椹木，米沢，和田：局部フィードバックをもつ空気式 オンオフ制御装置(続報), 第 6 回自動制御連合講演会 前刷, 195/196 (1963)

6）山口, 伊沢：オンオフ制御装置の提案, 日本機椷学会 第 42 通常総会学術講演会前刷集, 133, 101/104 (1965)

7）米沢, 五郎丸：フィードバック補償オンオフ制御の実 験的研究，計測自動制御学会論文集，3-2，142/148 (1967)

8）米沢，五郎丸，中塚：あるオンオフ制御系の調整条件 の検討, 制御工学, 11-10, 516/522 (1967)

9）米沢：オンオフ制御，計測 と制御，4-7，471/480 (1965)

\section{討論}

[伊沢計介]（東京工業大学）

1. Fig. 4 で示されている $K_{f} / K_{p}$ および $T_{1} / T_{p}$ の值はいずれも $V_{0}, V_{n}$ の関数であるが, 本論文に示 された調整方法を実際に適用するさい非常にめんどら ではないのか，異なった $V_{0}$ あるいは $V_{n}$ の值に対 し, Fig. 4 の曲線秥よび制御量の応答はどのように 変化するか。

2. 設定值変更に対する応答だけを議論してあるが， 外乱に対する応答はどらか。

\section{[筆者]}

1. 後述の関連質問と合わせて検討する。

2. 外乱に対する応答を調べるため現在すで報告さ れた調整条件と比較してみることにする. $h / A K_{p}=$ $0.05, L / T_{p}=0.4$ 乙いら制御系に有限時間幅の階段状 外乱を与えたさい，得られた結果を Fig. A.1 に示す。 

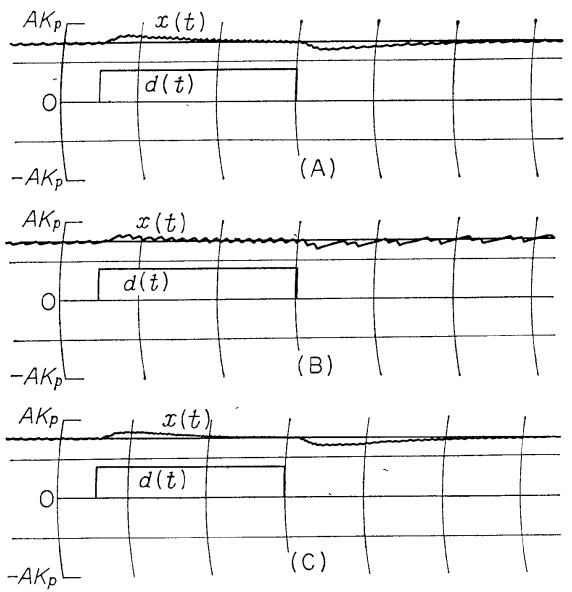

Fig. A.1 Effects of stepwise disturbance on controlled variable

それぞれ，(A）は椹木，米沢，和田5)，(B) は山口， 伊沢 ${ }^{6)}$, (C) は $V_{0} / A K_{p}=-0.5, V_{n} / A K_{p}=0.75$, $P / T_{p}=0.1$ とした本論文の調整条件による定常応答中 飞外乱を与えた場合の応答である. 本論文の調整パラ メータでは振動周期がかなり小さな值であるにもかか わらず，外乱に対して設定值に回復するまでの時間は， 他の調整条件と比較してもあまり長くを要しないこと がわかる。

\section{[久保 敦]（島津製作所）}

1. 立ち上がり時間がざだ時間とコンパラブル，な いしそれより小さくなったとき, 調整条件はどう変化 するか。

2. プロセスが高次（2 次）でたと艺ば，

$$
\frac{K_{p} e^{-L S}}{\left(T_{p} s+1\right)\left(0.1 T_{p} s+1\right)}
$$

のようなとき，調整条件は定性的にどう変化するか。

\section{[筆者]}

1. 本論文では比較的大きな設定值変更量に対する 最短時間応答の調整条件を求めているので，ご質問の ように仮定（ii）よりはずれた場合には適用困難であ る。しかし，無理汇適用させようとした場合，最初の オンオフ要素の切換時点 $t_{s}$ がむだ時間 $L$ 亿等しいか, またはそれれより小さくなり，これを満足するよらな調 整パラメータでは制御量が新しい設定值に到達した後 の応答が亜くなる。

2. (二次遅れ) +(むだ時間) はつぎのような式で (一次遅れ) +(屯だ時間) 飞等価的に近似できる.

$$
\frac{K_{p} e^{-L s}}{\left(T_{p} s+1\right) \cdot\left(0.1 T_{p} s+1\right)} \fallingdotseq \frac{K_{p} e^{-\left(L+L_{e}\right)^{s}}}{T_{e} s+1}
$$

このとき，相対的さだ時間は，

$$
\frac{L+L_{e}}{T_{e}}=0.98 \frac{L}{T_{p}}+0.09
$$

之なり ${ }^{3)}$ ，一般にパラメー夕調整値は多少大きくなる。

〔田原康雄】（島津製作所）

新・旧両設定值を考慮してある点，たいへん興味深
く拝見した。また調整パラメータが $\pm 10 \%$ 変化した ときの影響について検討してあることについても実用 的には意味があると思う。これ関してつぎの点につ いてご教示願いたい。

設定值急変量について, 通常の制御系では広範囲に 変化させる必要があるが，このとき調整パラメータも 大幅に変化させる必要があるかぞうか．本来パラメー 夕は被制御系が一定であれば設定值によって変化する のは望ましくないと思う。調整パラメータを一定をす ると設定值による制御性能の影響はどうなるか。

\section{〔筆者〕}

新，旧両設定值を含んだ本論文の調整条件では調整 パラメータの值は数值計算によらなければならない。 異なった $V_{0}$ あるいは $V_{n}$ に対する調整パラメータの 数值計算例を Fig. A.2 和よび Fig. A.3 に示す. これより調整パラメータの值は新・旧禹設定值によっ て変化し, 特に新しい設定値の大いさによって著しく 影響されることがわかる。これは決して望ましいこと ではないが棈造簡単，保守容易なオンオフ制御装置に よって本文に示されたよらな最適応答が得られるので あるから，たと光前もって数值計算を必要としても， な频から大きなメリットがあると考光るのが妥当では ないだろらか。

調整パラメータを固定して执いて，種々の值の $V_{n}$ に対するステップ応答を Fig. A.4 に示す。ここでは 調整パラィータは $h / A K_{p}=0.05, L / T_{p}=0.6, P / T_{p}=$ 0.1， $V_{0} / A K_{p}=-0.5$, 乙かも $V_{n} / A K_{p}=0.75$ のとき の值を適用した、 $V_{n}$ の值が小さくなると, 制御量が 設定值に到達する以前にオンオフ要素の切換の影響が

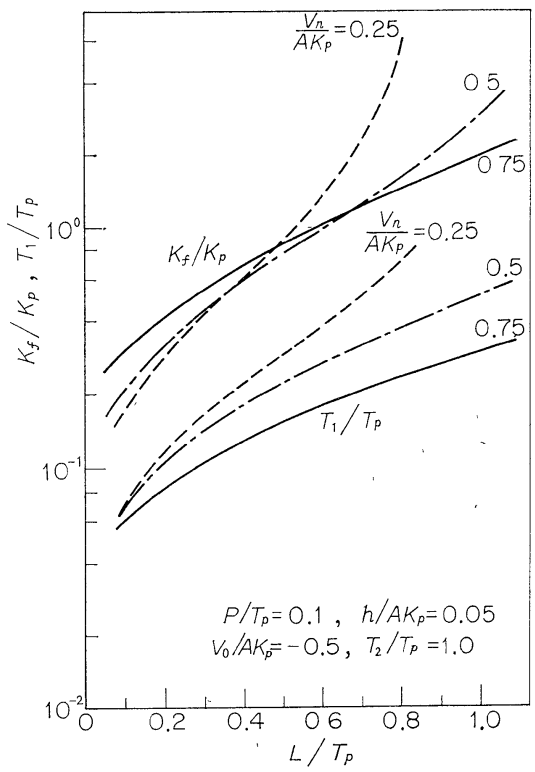

Fig. A.2 Optimum values of ajustable parameters for various set points 


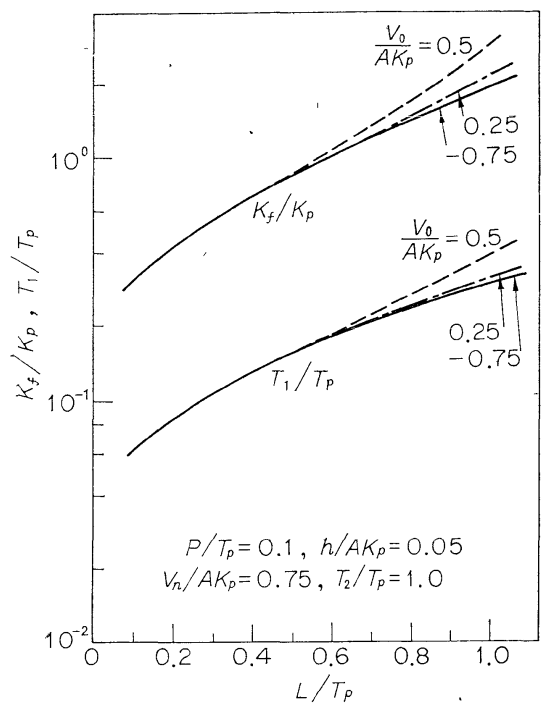

Fig. A.3 Optimum values of ajustable parameters for various sett points

あらわれ，最短時間応答を得ることができなくなる。

な和，最短時間応答に対するむだ時間の変化の影響 を調べるため, $h / A K_{p}=0.05, P / T_{p}=0.1$ でしかも $L / T_{p}=0.5$ の場合の調整パラメータを固定して $L$ を 種々の值にしたとき，得られたステップ応答を Fig. A.5 汇示す. $L / T_{p}<0.5$ なる範囲，すなわち $t_{s}>L$ なる仮定が成立する範团では制御量はオーバシュート を生ずるが，短時間で定常状態に拈ちつく．逆に， $L / T_{p}>0.5$ なる範囲で $t_{s} \leq L$ となった場合にはアン ダシュートを生じ，乙かも定常状態污沏ちつくまでに かなり長い時間を要する。

[北川 栄] (茨城大学工学部)

仮定が定性的であって定量的でないのが多少気似か かる，仮定がどれ汪ど実際成立するのか，仮定と実 際上のくるいがいか汪どあで許容されるのかに疑問が 残亏.

小さな電気炉でも使って実験して和くと，この理論 がはるかに強力になると思う。

以上のような考光方はどこまで行なってもきりはな いと思うが，実験すると案外なことを知ることは多く 経験している，計算機と違い，手をくうと思うがやっ てみる価值はないだろうか。

〔筆者】

もっともなご意見であると思う，実験については目 下検討中である.

仮定が成立する変数および定数の領域を定量的に求 めるのは系の本質上かなり困難であるが，アナコム演 算結果では $P / T_{p}<0.15, h / A K_{p}<0.1$ であ机ば良好 な制御成積が得られることが判明している. $L / T_{p}$ と $V_{n} / A K_{p}$ の影響については Fig. A.2 预よび Fig. A ・3を参照していただきたい。
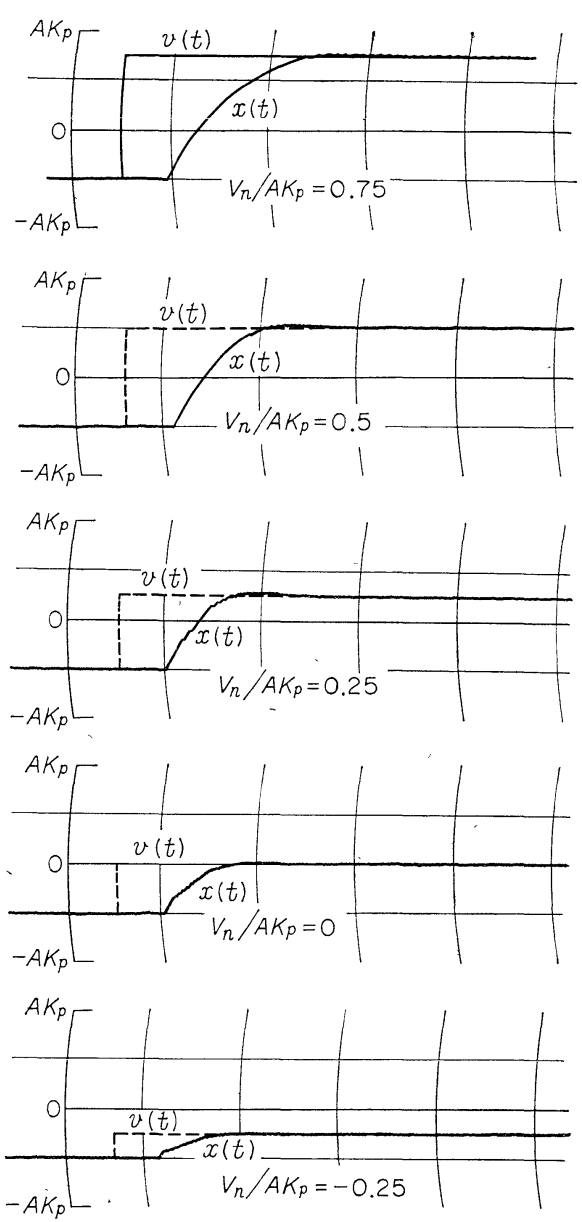

Fig. A.4 Effects of set point deviation on step response
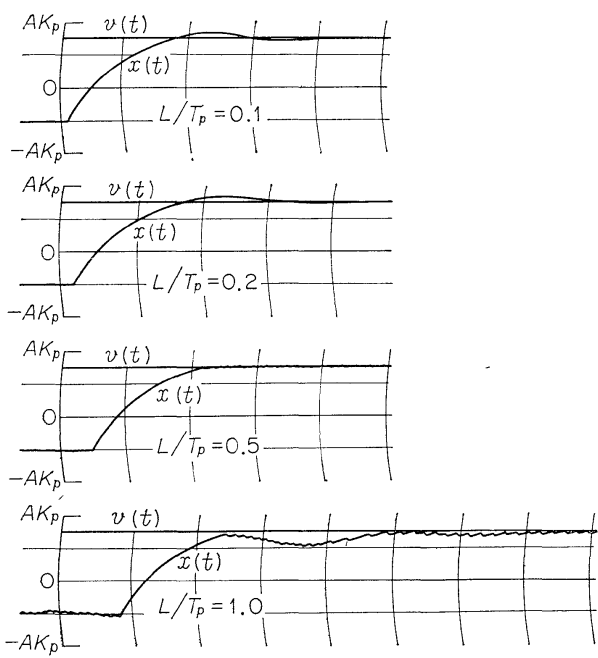

Fig. A.5 Effects of dead time deviation on step response 